\title{
FISHES OF THE ESTUARIES OF MIMIKA DISTRICT, PAPUA PROVINCE
}

\author{
Abdul Haris*, Deky Lala and Gesang Setyadi \\ PT. Freeport Indonesia. Environmental Department. Timika Environmental Laboratory \\ PO. BOX 109 Timika 98663, Papua, Indonesia. \\ *e-mail:abdul_haris@fmi.com
}

\begin{abstract}
Study on estuarine fishes in Mimika district, Papua was carried out at six estuaries from 2000 to 2006, as a part of monitoring program conducted by PT Freeport-Indonesia. This study mainly aimed to document the fish diversity, dominance, abundance and weight. Samples were collected from six estuaries, namely Ajkwa (tailing affected estuary), Tipoeka (disturbed estuary), Minajerwi, Kamora, Mawati and Otakwa (tailings unaffected estuaries). The total fish catches from the study sites during the study were 133 species belonging to 50 families, with the total abundance and wet weight were 85,523 individuals and $1,834 \mathrm{~kg}$, respectively. The indices of diversity and evenness ranged $1.1-2.1$ and $0.4-0.8$, respectively. Based on the sample abundance, the dominant families consisted of pony fishes (Leiognathidae), drum fishes (Sciaenidae) and anchovies (Engraulidae), catfish (Ariidae) and glassfish (Ambassidae), whereas based on the samples weight, the dominant families comprised of Sciaenidae, Ariidae, Leiognathidae, Engraulidae and Clupeidae. The results show that there were no significantly differences in diversities and abundances among the six estuaries of Mimika district.
\end{abstract}

Keywords: Estuarine fish, Diversity, Abundance, Wet weight, Papua

\section{INTRODUCTION}

Mimika district is located in the southern part of Papua with the mountain range in the highland and many swamps and estuaries in the lowland. Highland rivers carry large natural sediment loads from the mountains to the lowland and then to the estuaries and Arafura Sea due to the steep mountain slope and high rainfall rates (the highest rainfall rates in the world, Collison et al., 1997). These estuaries are fringed by densely mangrove forests. The water of these estuaries is turbid due to the naturally high suspended solids, which in turn create high rates of sedimentation.

The Ajkwa estuary of Mimika district in particular receives not only natural sediment but also some fraction of tailings due to the by-product of ore processing in the highland that result in high rates of sedimentation. Tailings as the waste of mining activities are sand and smaller size of ground native rocks consists of sediment particles which have the similar physical characteristic to natural sediment of the same grain size and heavy metals mainly copper (Collison et al., 1997).
The diversity of fishes in mangrove estuaries varies significantly at a number of scales; global, latitudinal, regional, local, and among habitats within individual systems. The number of species in a system represents the combined influences of factors operating at each of these scales (Blaber, 2007). At regional level, for example, the species composition is influenced mainly by habitat diversity, structure and hydrology. It is shown in the results of the study of Embly and Norman estuaries in the Gulf of Carpenteria, Australia. Embly estuary that has a broad range of habitats, including extensive mangrove forests, a variety of substrata and less extreme hydrological conditions has twice number of fish species than those in Norman estuary that has narrow fringe mangroves, soft muddy substrata, a large tidal range ( $>4 \mathrm{~m}$ ), extreme salinity and high current speeds (Blaber et al., 1994). Blaber (1981) stated that most of the estuarine fishes of the tropics are not the estuarine per se, but are characteristic of shallow turbid areas, often with variable salinities. These areas occur over very large areas of the sea in south and southeast Asia, west Africa, northern 
south America, east Africa, eastern Australia and parts of the United State of America. All of these areas and their fishes coincide with regions where mangroves are primary habitat types. De Graf and Xuan (1998) indicated that 1 ha of mangrove forest in Vietnam supports a marine catch of $450 \mathrm{~kg} \mathrm{yr}^{-1}$. Even Quinn and Kojis (1987) showed that mangrove estuaries in northeast Papua New Guinea are nursery areas for a few species of coral fishes. Blaber and Milton (1990) in a study of 13 small Solomon Islands mangrove estuaries showed that these systems had an insignificant role as nurseries for coral reef fishes. Dorenbosch et al. (2005) obtained similar results in east Africa. Verweij et al. (2006) showed that the recent experimental results from the Caribbean emphasize the different responses by juveniles of various reef species to the structure, food, and shade offered by mangroves, but clarify that the presence of these features contributes significantly to their attractiveness to juvenile reef fish.

The study on fishes of the six estuaries of Mimika district was carried from 2000 to 2006. This study is in conjunction with the monitoring program conducted by PT Freeport-Indonesia. The aim of this study was to understand the diversity, dominance, abundance and weight of fishes from the estuaries of Mimika district and the comparisons with the Ajkwa as tailings affected estuary, Tipoeka as disturbed estuary, and Minajerwi, Kamora, Minajerwi and Otakwa as tailings unaffected estuaries.

\section{MATERIALS AND METHODS}

\section{Sampling locations}

The sampling locations consisted of 6 mangrove estuaries, i.e. Kamora, Tipoeka, Ajkwa, Minajerwi, Mawati and Otakwa (Fig. 1). These sampling locations could be classified into tailings unaffected estuaries, tailings affected estuary and disturbed estuary (Table 1). Two stations were established at each sampling location (Fig. 1).

The water depths of these stations ranged between 3.0 and $10.0 \mathrm{~m}$. All the stations were located within the estuaries. The position of each trawl station was recorded by GPS unit.

\section{Sample collection and analysis}

Sampling was carried out twice a year (every semester) from 2000 to 2006 . The fishes were collected using otter trawl at each station. The net of the otter trawl is $11.0 \mathrm{~m}$ long, $1.5 \mathrm{~m}$ high and $35.0 \mathrm{~mm}$ mesh size and the net of the end bag is

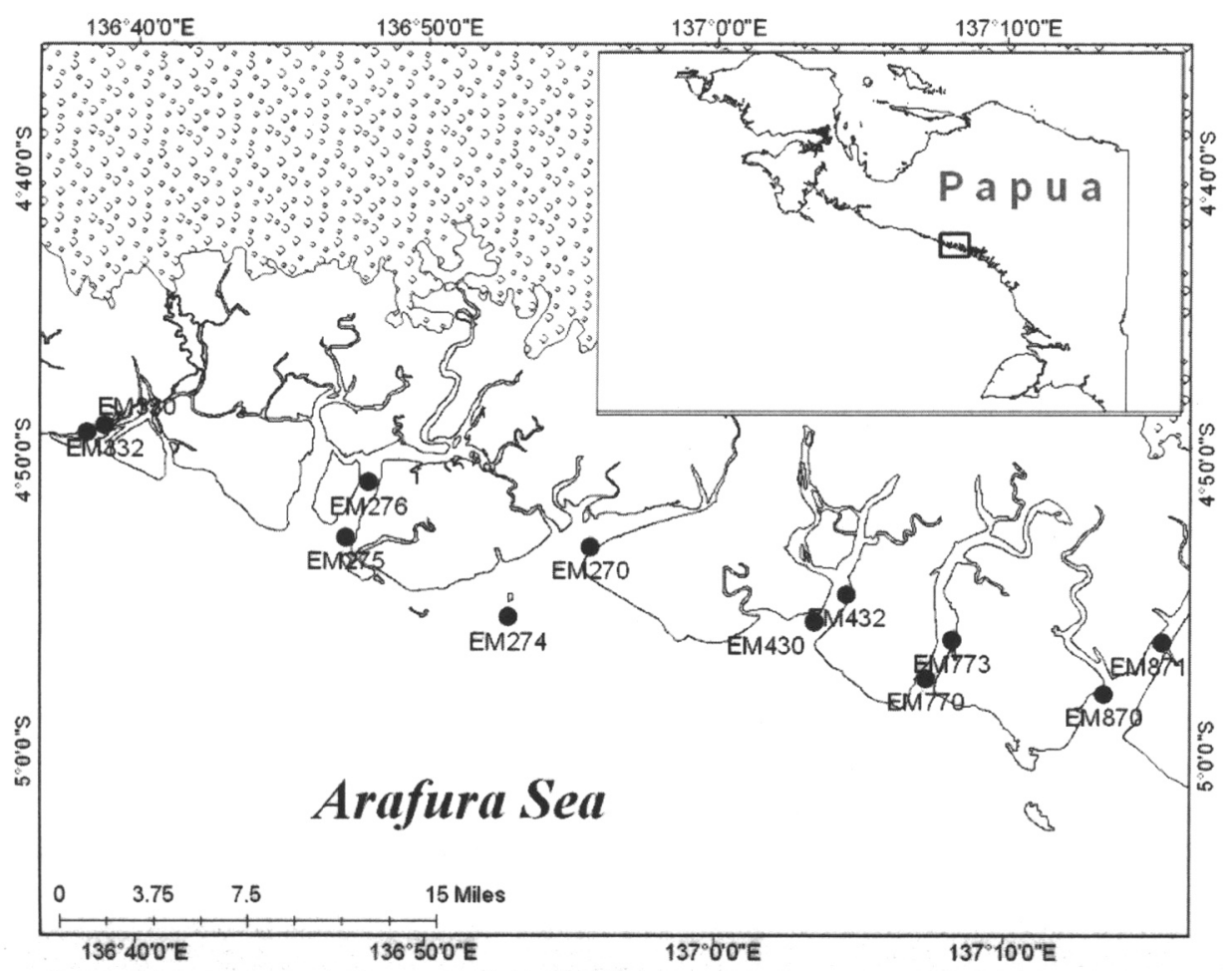

Figure 1. Sampling stations established in each estuary for study on fishes in Mimika District from 2000-2006. 
Table 1. Total numbers of family and species of each estuary during the study period (2000 - 2006).

\begin{tabular}{|l|l|l|}
\hline No. & Sampling sites & Classification \\
\hline 1. & Kamora & Tailings unaffected estuary \\
\hline 2. & Ajkwa & Tailings affected estuary \\
\hline 3. & Tipoeka & $\begin{array}{l}\text { Disturbed estuary due to the harbor activities (Amamapare habor) and shipment } \\
\text { of concentrate (product of ore processing) }\end{array}$ \\
\hline 3. & Minajerwi & Tailings unaffected estuary \\
\hline 4. & Mawati & Tailings unaffected estuary \\
\hline 5. & Otakwa & Tailings unaffected estuary \\
\hline
\end{tabular}

$20.0 \mathrm{~mm}$ mesh size. The net was towed at each station during day time for 10 minutes with the speed of $5 \mathrm{~km} / \mathrm{hr}$. After towing the net was lifted up and placed on the sorting table. Each sample was sorted out based on the family. After sorting the fishes were put in the plastic bags and kept in the ice box. In the laboratory, the fishes were identified up to species level if possible following Munro (1967), Gloerfelt-Tarp and Kailola (1984), Allen (1985), Whitehead et al. (1988), McKay (1992), Last and Stevens (1994), Carpenter and Volker (1999), and Kailola (2000). The fish samples were also counted and weighed of the total catch of each species using electronic balance to the nearest gram.

\section{Data analysis}

Diversity index $\left(\mathrm{H}^{\prime}\right)$ were calculated using Shannon- Wiener index, as follows:

$$
H^{\prime}=-\sum_{i=1}^{S} P_{i} \ln P_{i}
$$

Where $\mathrm{H}^{\prime}$ is the index of species diversity, $\mathrm{S}$ is the number of species, and $\mathrm{P}_{\mathrm{i}}$ is the proportion of total sample belonging to $i$ th species.

Species evenness (E) was calculated by Pielou's index, as follows:

$$
E=\frac{H^{\prime}}{\ln S}
$$

Where $\mathrm{H}^{\prime}$ is the index of species diversity, $\mathrm{S}$ is the number of species.

Two ways Anova was used to analyze the significant differences of fish community structure among the six sampling locations during the study period $(2000-2006)$.

\section{RESULTS}

\section{Species diversity}

The total numbers of families collected from the six estuaries during the study period (20002006) were 133 species belonging to 50 families (Appendix 1, Table 2). Mainly, the families of fishes distributed among the estuaries and the total number of family in each estuary was around 30 with the number of species ranged between 70 and 83 (Table 3). Ajkwa and Kamora estuaries had the highest numbers of species.

In terms of species diversity, five families had higher numbers of species, i.e. Ariidae, Carangidae, Sciaenidae, Engraulidae and Leiognathidae. The families of Ariidae and Carangidae were the dominant families of these estuaries and followed by Sciaenidae (Appendix $1)$.

Figures 2 and 3 show the diversity and evenness indices of the estuaries at each year. The values of diversity indices were low, ranging from 1.10 to 2.10 . The highest value (2.10) was found

Table 2. Categorization of sampling sites based on the condition of sedimentation.

\begin{tabular}{|l|c|c|c|c|c|c|}
\hline \multicolumn{1}{|c|}{ Family/species } & Ajkwa & Kamora & Mawati & Minajerwi & Otakwa & Tipoeka \\
\hline Total number of family & 33 & 34 & 34 & 33 & 32 & 33 \\
\hline Total number of species & 81 & 83 & 73 & 76 & 70 & 72 \\
\hline
\end{tabular}




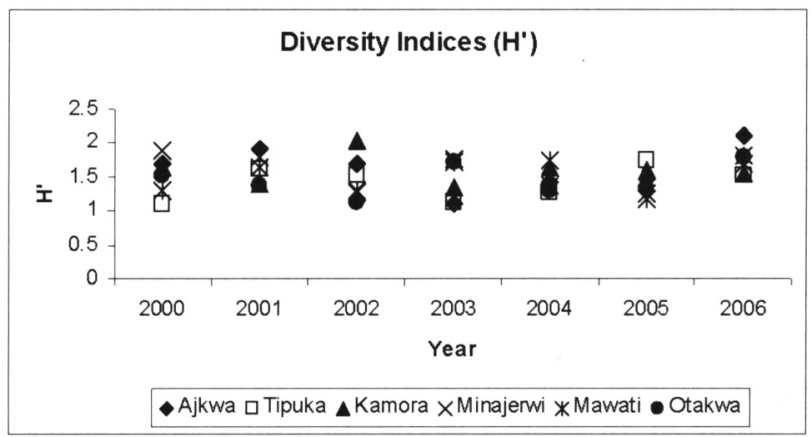

Figure 2. Diversity indices ( $\left.\mathrm{H}^{\prime}\right)$ of fish communities in 6 mangrove estuaries, from 2000-2006.

in Ajkwa estuary in 2006 and the lowest values were in Tipoeka (2000) and Ajkwa (2003) estuaries.

The values of evenness indices (e) ranged between 0.4 and 0.8 . The lowest $(0.4)$ and the highest $(0.8)$ values were found in Otakwa estuary in 2002 and 2003 respectively. The majority of the evenness index values were between 0.5 and 0.6 , indicated the dominant species were found mostly at every estuary of each year.

\section{Samples abundance and wet weight}

The family compositions based on the high abundances and wet weight during the study period are illustrated in Figures 4 and 5. The dominant families based on the high abundance were Leiognathidae (ponyfishes), Ariidae (catfish), Sciaenidae (drumfishes), Engraulidae and Clupeidae (anchovies) and Ambassidae (glassfishes) (Fig. 4).

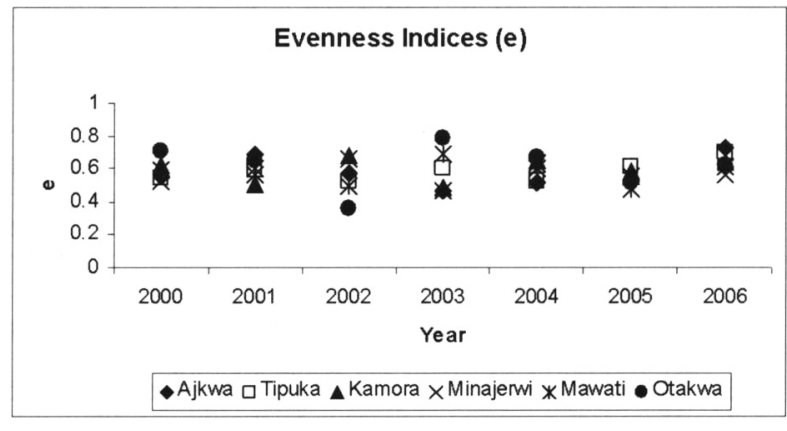

Figure 3. Evenness indices of fish communities at 6 mangrove estuaries at each year, from 2000 2006.

Ninety percent of the species of the families of Ariidae and Sciaenidae were found in Ajkwa estuary with high abundances and high in wet weight. Particularly, the species of the family Ariidae were abundant in Ajkwa estuary, whereas in the other estuaries they were few. Besides family Ariidae, the family Abassidae especially the species Ambassis dussumieri, families Clupeidae and Engraulidae were also dominated Ajkwa estuary.

Based on the wet weight, the dominant families were Sciaenidae (drumfishes), Ariidae (catfishes), Leiognathidae (ponyfishes), Engraulidae and Clupidae (anchovies) (Fig. 5).

The result of two ways ANOVA analysis showed that there were no significantly differences of diversity and abundance of fishes among the 6 mangrove estuaries with $p>0.05$

The result of two ways ANOVA analysis (Table 6) showed that there were no significantly

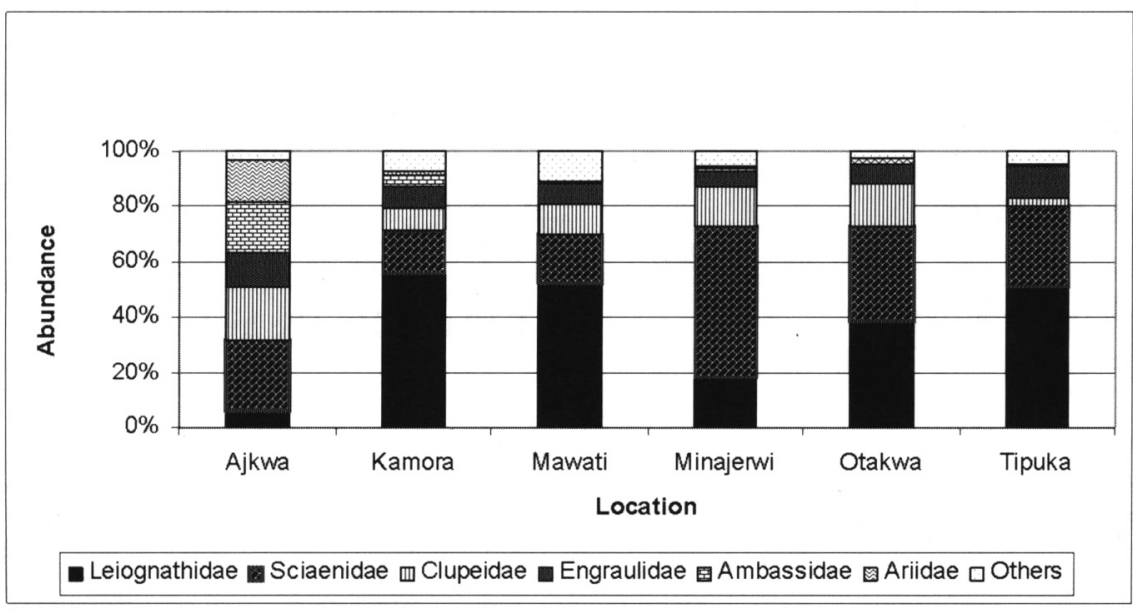

Figure 4. Family composition based on high abundance in each mangrove estuary during the study period. 


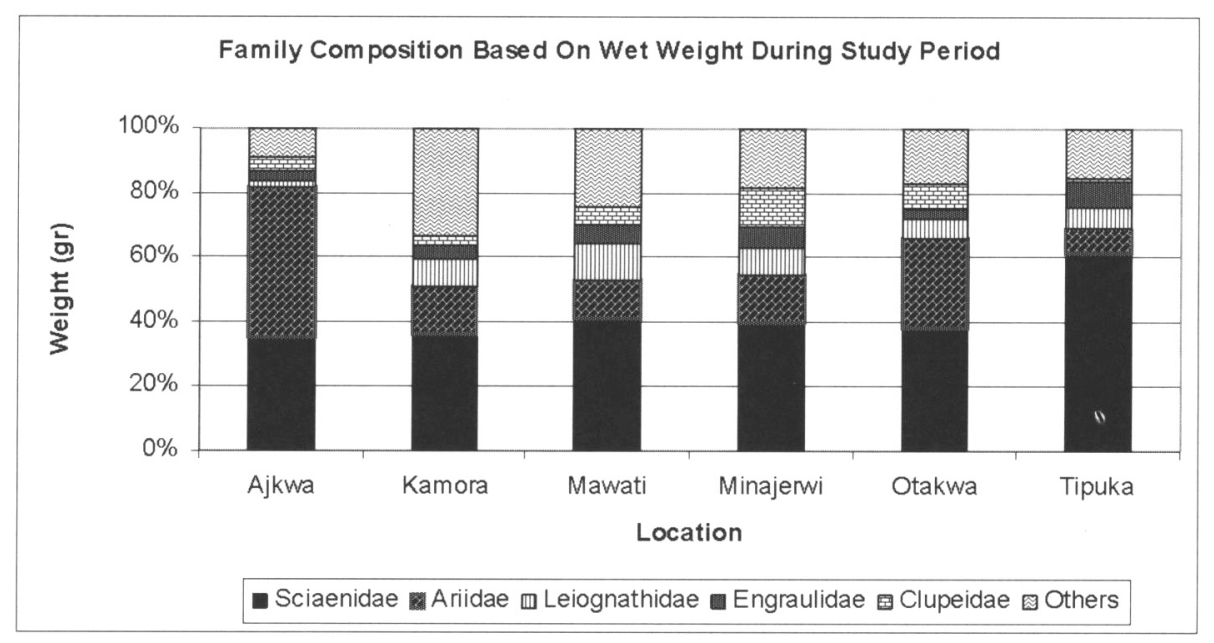

Figure 5. Family composition based on wet weight in each mangrove estuary during the study period.

Table 6. ANOVA results for diversity and abundance of fishes in the 6 mangrove estuaries for 2000-2006.

\begin{tabular}{|c|c|c|c|c|c|c|}
\hline Sources & SS & $d f$ & MS & $F$ & $P$-value & $F$ crit \\
\hline \multicolumn{7}{|l|}{ Diversity } \\
\hline Years & 0.45 & 6 & 0.07 & 1.11 & 0.38 & 2.42 \\
\hline Sites & 0.25 & 5 & 0.05 & 0.72 & 0.61 & 2.53 \\
\hline Error & 2.04 & 30 & 0.07 & & & \\
\hline Total & 2.74 & 41 & & & & \\
\hline \multicolumn{7}{|l|}{ Abundance } \\
\hline Years & 808438.5 & 6 & 134739.8 & 1.10 & 0.38 & 2.42 \\
\hline Sites & 970391.3 & 5 & 194078.3 & 1.58 & 0.19 & 2.53 \\
\hline Error & 3681612.0 & 30 & 122720.4 & & & \\
\hline Total & 5460442.8 & 41 & & & & \\
\hline
\end{tabular}

differences of diversity and abundance of fishes among the 6 mangrove estuaries with $\mathrm{p}>0.05$.

\section{DISCUSSION}

The total number of the fish families collected from 6 mangrove estuaries during the study period (2000-2006) was 50 comprising 133 species. The numbers of families and species of each estuary was around 30 and between 70 and 85 , respectively (Table 2). Erftemeijer (in Tomascik et al., 1997) studied the mangrove-associated fish species in mangrove-Nypa waterways of Bintuni Bay (undisturbed mangrove habitats), Papua and the lagoon of Segara Anakan (disturbed mangrove habitats), Java. The number of family of fishes of both locations were around 30 but the number of species was lower in Segara Anakan (40 species) than those in Bintuni Bay (59 species). According to the number of family the result of present study was comparable with those in Bintuni Bay and Segara Anakan.

The composition of mangrove fish assemblages is determined by interplay of factors that include structural diversity of habitat, hydrological features of current speed, tidal range, turbidity and salinity, and the nature of adjacent waters. The fish assemblage in any one mangrove system is the result of the combined effects of all of these factors and the relative importance of each (Blaber, 2007).

The species diversity indices of fishes of the mangrove estuaries of Mimika district were low ranging from 1.10 to 2.10 . This low diversity might be due to the wide environmental fluctuation of the study sites. According to the annual water quality data base of Environmental Department 
of PT Freeport Indonesia, salinity, turbidity, total suspended solid (TSS) and tide ranged 1.39-30.7 $\%, 1.8-387.0 \mathrm{NTU}, 1.0-1780.0 \mathrm{mg} \mathrm{l}^{-1}$ and 0.2 $-3.2 \mathrm{~m}$, respectively (unpublished data), and the high rainfall rates. This harsh environment caused the low species diversity of fishes, only the species could adapt this condition would survive.

Hayase and Fadzil (1999) studied the distribution and abundance of fish in Matang and Merbok mangrove waters. Matang has large and diverse mangrove forest covering many square kilometers, while Merbok has only fringing stands of mangrove. The species of fish collected from Matang was 117 while about half of this number have been recorded in the Merbok. Although the numbers of species are different, the dominant families in both are Ariidae and Sciaenidae. The present study found the families Ariidae and Carangidae (based on the number of species) were the dominant ones but based on the high abundance, Ariidae and Sciaenidae were the dominant families. The species of the family Carangidae collected from these estuaries had very low abundances with the highest abundance was only 10 individuals (Appendix 1.). It might be due to among Carangidae, juveniles of only some species are estuarine dependent and most are not (Blaber and Blaber, 1980).

Based on the high abundance, 6 families dominated these estuaries, i.e. Ariidae, Ambassidae, Clupeidae, Engraulidae. Leiognathidae and Sciaenidae. The families Ariidae, Ambassidae, Clupeidae, Engraulidae and Sciaenidae dominated the Ajkwa estuary (Fig. 4). It might be due to the availability of food. According to the results of monitoring benthic fauna in these estuaries, Ajkwa estuary is dominated by the capitellids (polychaetes) known as colonizers of disturbed aquatic habitats, occurring at very high densities $\left(9,635.00-9,983.33\right.$ ind. $\left.\mathrm{m}^{-2}\right)(\mathrm{PT}$ Freeport-Indonesia, 1995-2006). The study of stomach content of fishes collected from the estuaries of Mimika district revealed the small sized species, Johnius spp. $(2.0-4.0 \mathrm{~cm})$ belongs to the family Sciaenidae fed on polychaetes with various degraded conditions, nematods (meiofauna), amphipods (small crustaceans) and detritus. The bigger sized species of Ariidae (5.0 $10.0 \mathrm{~cm}$ ), Arius spp. fed on small fish, crabs, bivalves, etc. (unpublished data, 1999). It is suggested that these fishes are bottom-feeding fishes which depend on the benthos. Spies (1984) who studied benthic-pelagic coupling in sewage-affected marine ecosystems found the proportion of infaunal polychaetes increased and the proportion of crustaceans decreased with increasing wastewater influence. At the two most affected stations, crustaceans were virtually absent and the opportunistic polychaetes, Capitella capitata and a small dorvelleid polychaetes were abundant. The four species of fishes, i.e. Zaniolepis latipinnis, Icelinus quadriseriatus, Symphurus atricauda and Citharicthys stigmaeus found at the least affected stations had higher densities and their diets were dominated by crustaceans. If they occurred in the most effected stations they shifted towards consuming much larger numbers of polychaetes. It suggested that the number of fish and fish diversity were negatively and more closely correlated with the gradient of wastewater influences $(p=0.02-0.05$ and $r<-0.6$ ) rather than the abundance of preys. It was concluded that altered communities of fishes were the result of negative impacts to benthos.

Based on the wet weight, the dominant families were Ariidae, Engraulidae, Clupeidae, Leiognathidae and Sciaenidae. Most of these families had big sized species, such as ariids and sciaenids collected from Mimika estuaries had the ranges of mean total lengths between 8.0 and 80.0 $\mathrm{cm}$ and from 4.0 to $67.7 \mathrm{~cm}$, respectively. Ajwa estuary was dominated by the families Ariidae and Sciaenidae in terms of wet weight and it is in accordance with the high abundances and big sized species.

The result of two ways ANOVA analysis showed that there were no significantly differences of diversity and abundance of fishes among the six mangrove estuaries. Ajkwa estuary is receiving not only natural sediment from the highland river but tailings as well which contain high copper concentration. It was assumed this copper would deteriorate fish fauna of this area. According to Stauber (1995) most copper in the river with high levels of dissolved organic matter is not bio-available due to its complexation with this organic matter and so would not be expected to have toxic effects on aquatic life. Since the dissolved organic matter is high in the estuaries of Mimika district due to the very dense and old mangrove forests with high amount of degraded detritus stranded on the river bank, the copper would not have toxic effects on the fish fauna. Hortle et al. (1997) also reported that the number 
of species and abundance of fish fauna among the estuaries of Mimika were not significantly different. Therefore, during the study from 2000 2006, fishes collected from six estuaries with different environmental conditions had no significant differences in diversities and abundances.

Acknowledgement. We are grateful to the team of Manager of PT Freeport Indonesia for giving us the opportunity to present the fish data of this company and reviewing this manuscript. We also thank the technicians of PT Freeport Indonesia for helping us in processing the data. We also thank Amiruddin, staff of Marine and Coastal Division of Environmental Department for drawing the map.

\section{REFERENCES}

Allen, G.R. 1985. Snappers of the word. An Annotated and illustrated catlogue of lutjanid species known to date. FAO species catalogue. Vol. 6. Food and Agriculture Organization of the United Nations, Rome. 208pp + 28 plates.

Blaber, S.J.M. 2007. Mangroves and fishes: Issues of diversity, dependence, and dogma. Bull. Mar. Sci., 80(3): 457-472.

Blaber, S.J.M., and D.A. Milton. 1990. Species composition, community structure and zoogeography of fishes of mangroves in the Solomon Islands. Mar. Biol. 105: 509-531.

Blaber, S.J.M., and T.G. Blaber. 1980. Factors affecting the distribution of juvenile estuarine and inshore fish. J. Fish Biol. 17: 143-162.

Blaber, S.J.M., 1981. The zoogeographical affinities of estuarine fishes in southeast Africa. S. Afr. J. Sci. 77: 305-307.

Blaber, S.J.M., D.T. Brewer, and J.P. Salini. 1994. Comparison of the fish communities of tropical estuarine and inshore habitats in the Gulf of Carpentaria, northern Australia. In: K.R. Dyer, and R.J. Orth (eds). Int. Symp. Series ECSA 22, Olsen and Olsen, Denmark: 363-372.

Carpenter. K. E., and H.N. Volker. 1999. FAO species identification guide for fisheries purposes. The living marine resources of western central Pacific. Food Agriculture Organization of the United Nation, Rome.Vol. 3: 2068 pp.

Collison, G.H.P.E., and W.F.P.E. Brumund. 1997. Conceptual Tailings Option Study. PT Freeport Indonesia - Golder Associates Georgia USA.
De Graaf, G.J., and T.T. Xuan. 1998. Extensive shrimp farming, mangrove clearance and marine fisheries in the southern provinces of Vietnam. Mangrove and Saltmarshes 2: 159-166.

Dorenbosch, M.M.C., M.G.G. Grol, J.A. Christianen, I. Nagelkerken, and G. van der Velde. 2005. IndoPacific seagrass beds and mangrove contribute to fish density and diversityon adjacent coral reefs. Mar. Ecol. Prog. Ser. 302: 63-76.

Gloerfelt-Tarp, T., and P.J. Kailola.1984. Trawled fishes of southern Indonesia and northwestern Australia. The Australian Development Assistance Bureau (ADAB), The Directorate of Fisheries, Indonesia (DGF) and The Germany Agency for Technical Cooperation (GTZ). 460pp.

Hayase, S., and M. Fadzil. 1999. Fish distribution and abundance in Matang and Merbok mangrove waters, west coast of peninsula Malaysia: II Preliminary results for 1996-1997. In: V.C. Chong and P.S. Choo (eds). Productivity and sustainable utilization of brackish water mangrove ecosystems. Japan International Research Center for Agricultural Sciences Tokyo, Japan: 59-91.

Hortle, K.G., J. Suprihatin, A. Haris, .S. Tekege, D. Lala, and P. Paryono, 1997. Report estuarine fish and invertebrate monitoring. Freeport contract of work area Irian Jaya, Indonesia May 1996-March 1997, PT Freeport Indonesia, Environmental Department Kuala Kencana, Irian Jaya, Indonesia.

Kailola, P.J. 2000. Six New Species of fork-tailed Catfishes (Pisces, Teleostei, Ariidae from Australia and New Guinea. The Beagle, Record of the Museums and Art Galleries of the Northern Territory. 16: 127-144.

Last, P.R., and J.D. Stevens 1994. Shark and rays of Australia. CSIRO, Australia. 513pp+84plates.

McKay, R. J. 1992. Sillaginid fishes of the world (Family Sillaginidae): An annotated and illustrated Catalogue of the sillago, smelt or Indo-Pacific whiting species:. FAO Species catalogue, Vol 12. Food and Agriculture Organization of the United Nations. Rome. 87pp.

Munro, I.S.R. 1967. The fishes of New Guinea. Department of Agriculture Stock and Fisheries Port Moresby, New Guinea.

PT Freeport- Indonesia. 1995-2006. Annual reports on estuarine benthic communities.

Quinn, N.J., and B.L. Kojis, 1987. The influence of diet cycle, tidal direction and trawl alignment on beam trawl catches in an equatorial estuaries. Environ. Biol. Fish 19: 297-308. 
Spies, R., 1984. Benthic-pelagic coupling in sewage-affected marine ecosystem. Mar. Envorn. Res. 13: 195-230.

Stauber, J. L. 1995. Toxicity testing using marine and fresh water unicellular algae. Aust. J. Ecotox., 1: $15-24$.

Tomascik, T., A.J. Mah, A. Nontji, and M.K. Moosa (eds.), 1997. The ecology of Indonesian seas Part Two Chapter Nineteen: Mangrove. The ecology of Indonesian series, Volume VIII. Periplus Editions.

Verweij, M.C.I., I. Nagelkerken, D. De Graaf, M. Peeters, E.J. Bakker, and G. van der Velde. 2006. Stucture, food and shade attract juvenile coral reef fish to mangrove and seagrass habitats: a field experiment. Mar. Ecol. Prog. Ser. 306: 257-268.
Whitehead, P.J. P., G.J. Nelson, and T. Wongratana. 1988. Clupeoid Fishes of the word (suborderm Clupeoidei): An annotated and illustrated catlogue of the herrings, sardines, pilchards, sprats, shads, anchovies and wolf-herrings: FAO Species catalogue. Vol. 7, Part 2-Engraulididae. Food and Agriculture Organization of the United Nations. Rome. 579pp. 


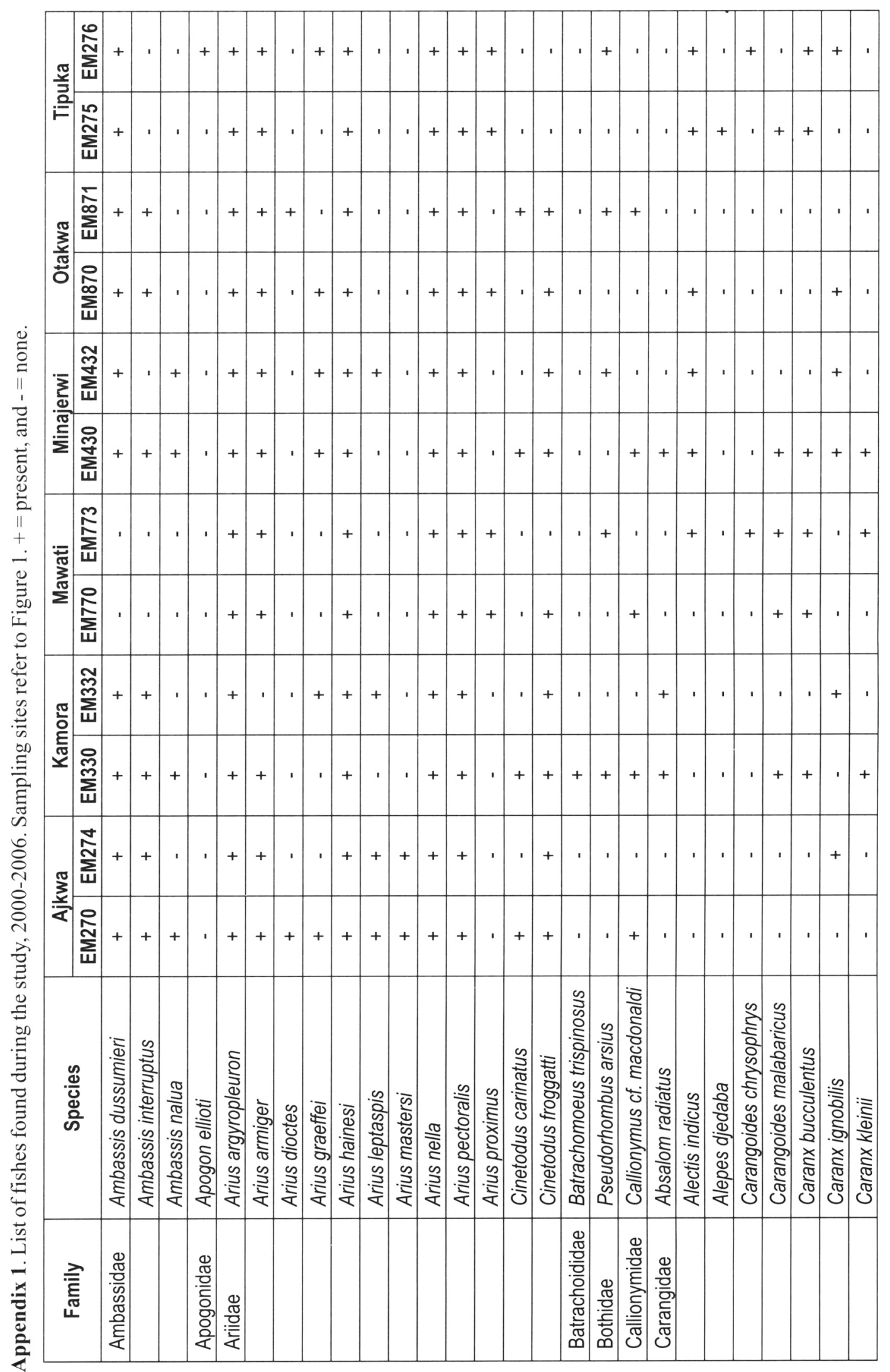




\begin{tabular}{|c|c|c|c|c|c|c|c|c|c|c|c|c|c|c|c|c|c|c|c|c|c|c|c|}
\hline 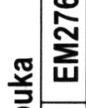 & + & + & + & + & & + & + & + & + & & & & + & +1 & - + & & + & + & + & + & + & + & \\
\hline ت & + & + & + & + & & + & + & & + & & & & + & ++ & ++ & & + & + & +1 & $\begin{array}{lll} & 1\end{array}$ & + & + & \\
\hline 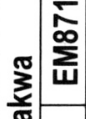 & & + & + & ' & & ++ & $1+$ & & & + & & ' & + & + & ' + & + & + & + & +1 & ' & ' & + & \\
\hline ot & + & + & + & $\cdot$ & & ++ & ++ & & ' & & + & ' & + & ++ & ++ & . & + & + & +1 & $\begin{array}{lll}1 & 1\end{array}$ & + & + & ' \\
\hline 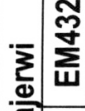 & + & + & + & & & +1 & $\begin{array}{lll}1 & 1\end{array}$ & & ' & & & & + & ++ & ++ & + & + & + & +1 & & & + & + \\
\hline 旁 & + & + & + & & . + & ++ & $+1+$ & ' & + & & & & + & ++ & ++ & + & & + & +1 & 1 & & + & + \\
\hline$=\frac{\tilde{E}}{\tilde{N}}$ & + & + & ++ & + & ' + & & & & + & & & & + &.+ & - + & & + & ++ & +1 & & & + & ' \\
\hline 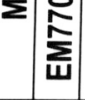 & + & + & + & & ' + & & & + & + & ' & ' + & + & +1 & ++ & + & ' & + & ++ & +1 & & +1 & + & \\
\hline 怘 & + & +- & + & & ' & & + & + & + & ' & ' & + & ++ & +1 & + & + & + & ++ & +1 & ' & & + & \\
\hline $\mathbf{x}$ & + & + & ++ & + & ' & & + & + & + & & & + & ++ & + & . & & + & ++ & ++ & & ++ & & $\begin{array}{l}1 \\
\end{array}$ \\
\hline 空 & & + & + & & + & $+1+$ & + & . & ' & ' & + & 1 & $+t$ & ++ & + & ' & & ++ & $\begin{array}{l} \\
\end{array}$ & + & & ++ & \\
\hline 啇 & & & +1 & $1+$ & $-1+$ & -11 & + & $\cdot$ & ' & \begin{tabular}{l|l} 
& 1
\end{tabular} & ' & 1 & + & ' + & ' & + & ' & ++ & $\begin{array}{l}+ \\
+\end{array}$ & ' & & ++ & + \\
\hline $\begin{array}{l}\frac{\mathscr{0}}{\mathbb{\Xi}} \\
\text { के } \\
\text { के }\end{array}$ & 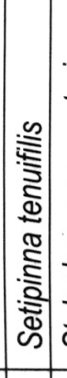 & 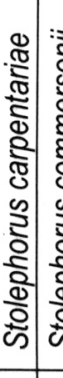 & 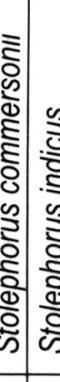 & 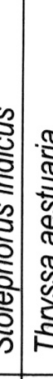 & 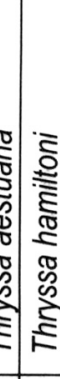 & 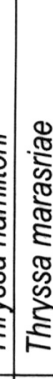 & 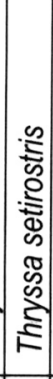 & 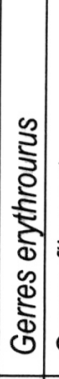 & 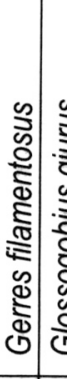 & 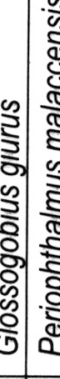 & 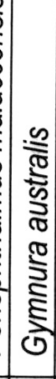 & 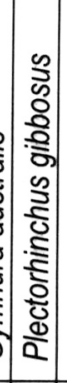 & 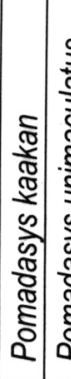 & 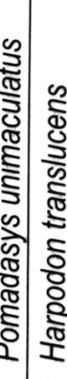 & 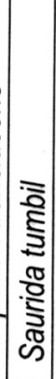 & 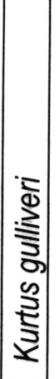 & 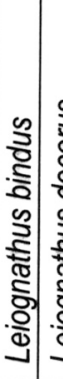 & 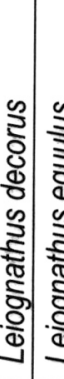 & 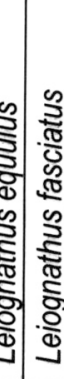 & 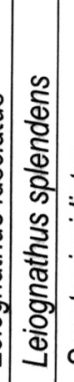 & 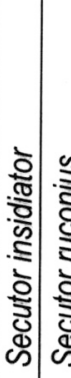 & 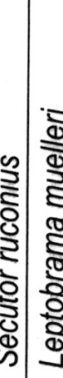 & 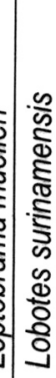 \\
\hline 彥 & 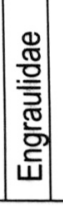 & & & & & & & 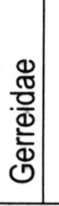 & i & 这 & 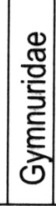 & 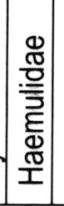 & & 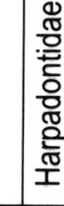 & & 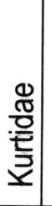 & 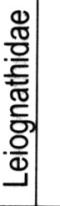 & & & & & & 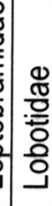 \\
\hline
\end{tabular}




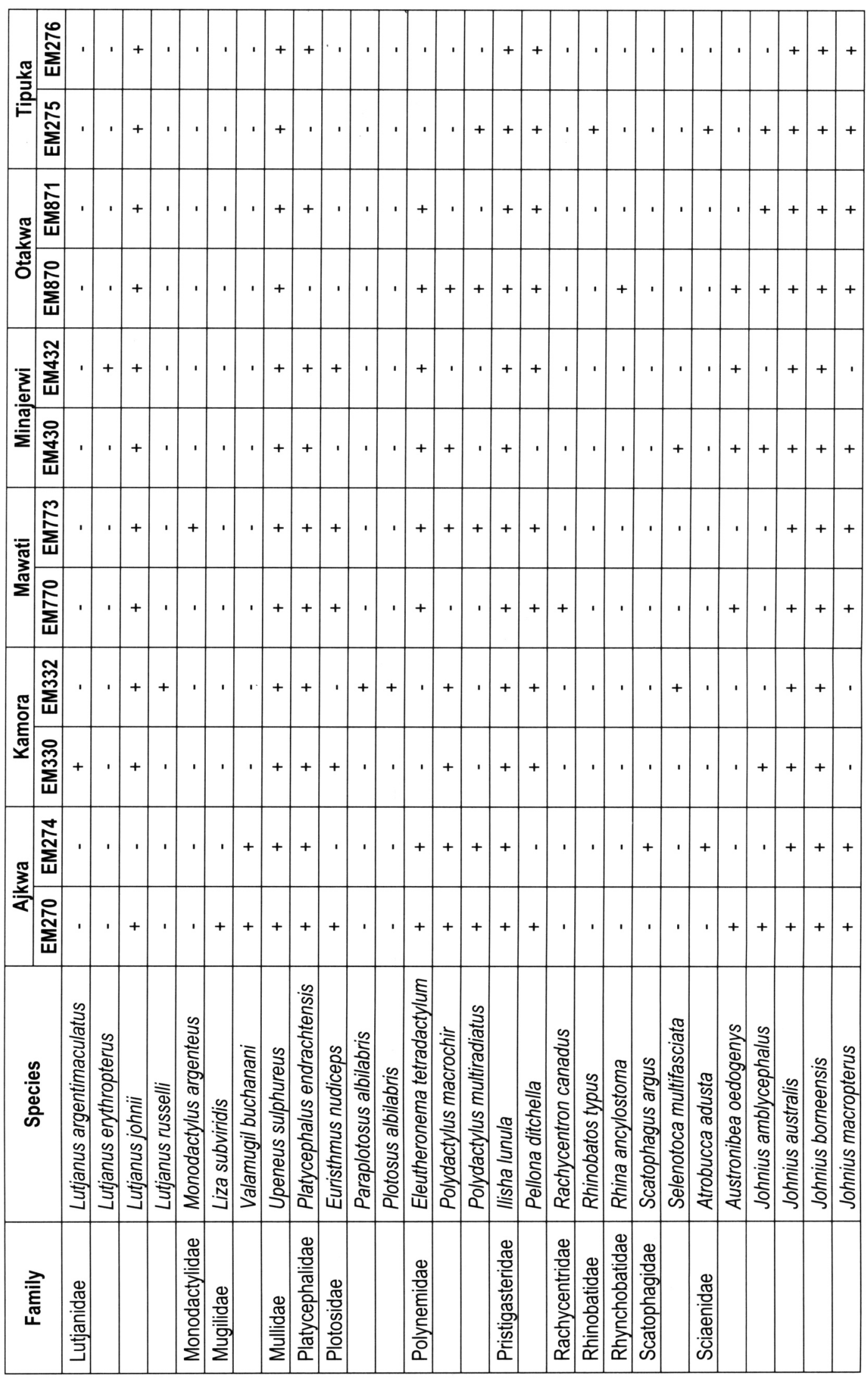




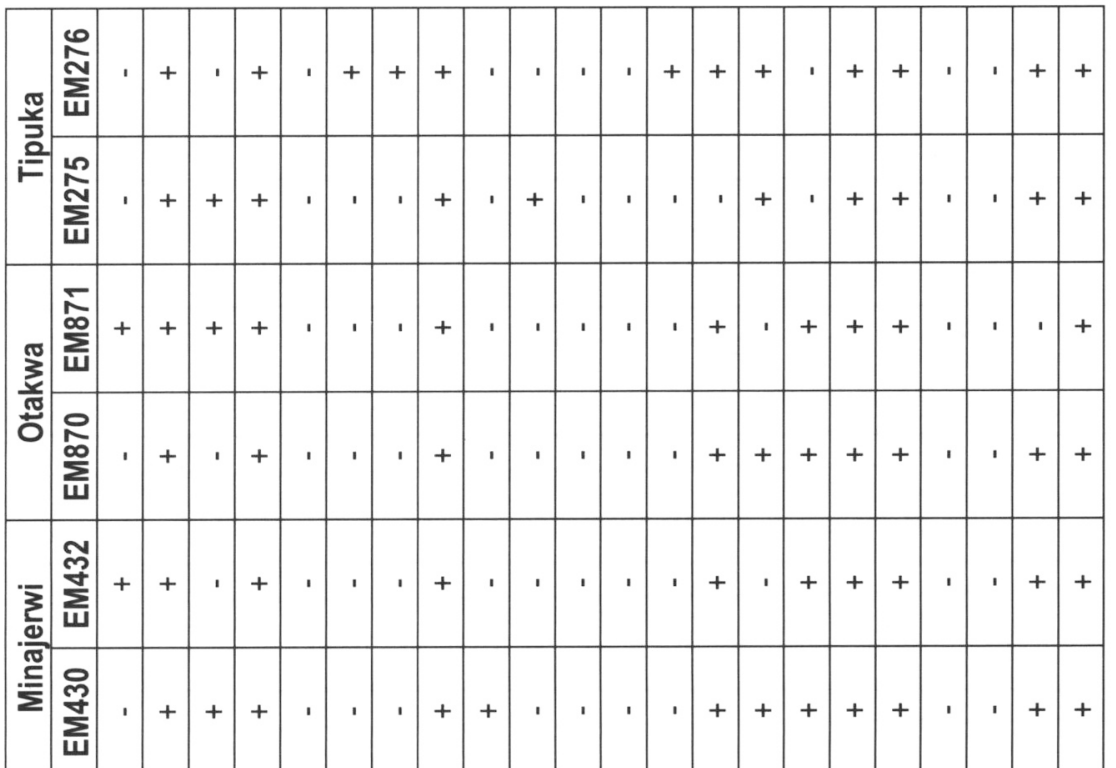

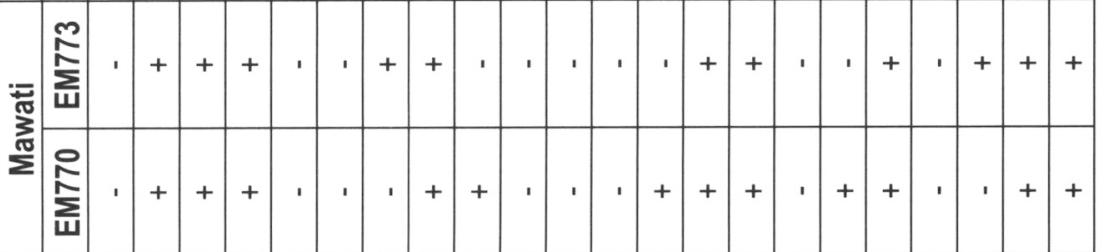

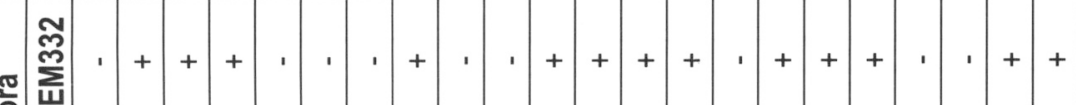

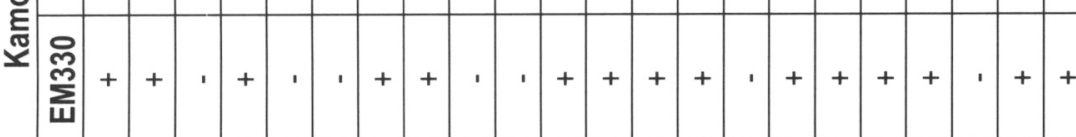


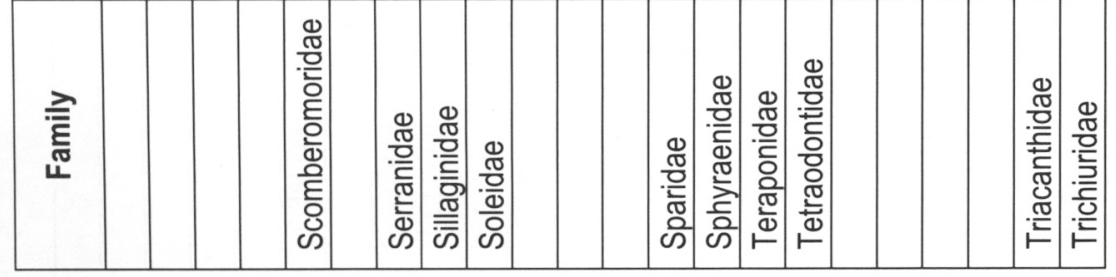

